DOI 10.20396/temáticas.v26i52.11710

\title{
DIVISÃO SEXUAL DO TRABALHO SOB A ORDEM NEOLIBERAL
}

\author{
Thais de Soura Lapa
}

\begin{abstract}
RESUMO: Este artigo procura trazer contribuições ao debate sobre a relação entre a divisão sexual e internacional do trabalho, procurando caracterizar não somente impactos do neoliberalismo sobre a divisão sexual do trabalho, mas mostrar, como vêm apontando sobretudo pesquisadoras feministas, que o gênero é um organizador chave da globalização neoliberal. Focalizo nessa discussão as dinâmicas da divisão sexual no trabalho assalariado e o uso estratégico da força de trabalho feminina em manufaturas que integram as cadeias globais de valor (com o exemplo emblemático da indústria eletroeletrônica), sem desconsiderar, porém, a indissociabilidade entre trabalho assalariado e reprodutivo.
\end{abstract}

PALAVRAS-CHAVE: divisão sexual do trabalho; neoliberalismo; cadeias globais de valor; terceirizações; setor eletroeletrônico.

\section{SEXUAL DIVISON OF LABOUR UNDER THE NEOLIBERAL ORDER}

\begin{abstract}
This article seeks to bring contributions to the debate on the relationship between the sexual and international division of labour, aiming not only to characterize the impacts of neoliberalism on the sexual division of labour but to show, as feminist researchers have been pointing, that gender is a key organizer of neoliberal globalization. I focus on this discussion the dynamics of the sexual division in paid work and the strategic use of the female labor force in manufactures that integrate the global chains of value
\end{abstract}

\footnotetext{
${ }^{1}$ Doutoranda em Ciências Sociais na UNICAMP, mestre em Sociologia pela USP. Contato: thais_lapa@yahoo.com.br
} 
(with the emblematic example of the electronics industry), without disregarding, however, the inseparability between paid work and reproductive work.

KEYWORDS: sexual division of labour; neoliberalism; global chains of value; outsourcing; electronics industry.

\section{INTRODUÇÃO}

O neoliberalismo tem como característica mais evidente o aumento do poder das finanças na economia, que traz em seu bojo um modo específico de acumulação do capital, denominado "acumulação flexível". Harvey (2008, p. 172) analisa que as práticas da acumulação flexível do neoliberalismo recuperam formas de "acumulação por espoliação", isto é, promovem uma continuidade e proliferação de práticas de acumulação que Marx tratara como "primitivas" ou "originais".

Harvey (2008, p. 171) considera "redistribuir, em vez de criar, riqueza e renda" como a principal realização da neoliberalização, processo que tem como principais mecanismos a privatização e mercadificação; a financialização; a administração e manipulação de crises e redistribuições via Estado (HARVEY, 2008, p. 173-177).

Neste modo de acumulação de economia financeirizada, deslocase a centralidade da grande indústria manufatureira como pólo de acumulação do capital, já que capitalistas têm a possibilidade, agora, de acumular a partir não somente da extração de mais valia, mas também da valorização do valor por meio de operações no mercado financeiro. Harvey (2004, p. 63) destaca, entretanto, que é da natureza da financeirização ser perpetuamente vulnerável à produção de valor na atividade industrial e agrícola. Isso significa afirmar que não existe no neoliberalismo uma independência plena entre capital produtivo e capital financeiro.

Esse novo sistema societário neoliberal surge em larga medida sob tutela norte-americana, uma vez que os EUA, "ameaçados no campo da produção, reagiram afirmando sua hegemonia por meio das finanças" (HARVEY, 2004, p. 58-59). Belluzzo e Galípolo (2017, p. 2) afirmam que a globalização provocou uma verdadeira revolução na estrutura econômica mundial e enfatizam que as três grandes transformações que ocorrem de 
forma concomitante - a reorganização da estrutura produtiva, a onda de fusões e aquisições que transformou o sistema financeiro e a centralização da propriedade - são processos conexos, que resultam na conformação das cadeias globais de valor.

Falar de reorganização do trabalho sob a ordem neoliberal implica, de um lado, discutir a divisão internacional do trabalho que conforma tais cadeias globais de valor - processo que, no mundo industrial, vem provocando uma grande mudança espacial das atividades produtivas, com a concentração do design nos países mais industrializados e da manufatura nos países onde a mão de obra é mais barata (LAPA e LEITE, 2017, p. 311). No entanto, analisar a reorganização do trabalho sob a ordem neoliberal significa, também, falar de uma reconfiguração da divisão sexual do trabalho ${ }^{2}$, que conjugada à divisão internacional, faz perceber entre outras coisas que cada vez mais os deslocamentos industriais para países periféricos significam utilização de mão de obra intensiva e, com frequência, de predominância feminina no trabalho em manufaturas, sobretudo nas nos setores eletrônico, de vestuário, além de sua presença significativa no crescente setor de serviços (LIPIETZ, 1989, ELSON, 2010).

A isso se soma um conjunto de debates que não se restringem ao trabalho assalariado e incorporam, também, as transformações sobre o trabalho reprodutivo sob essa ordem neoliberal, em coerência com um acúmulo teórico interdisciplinar nas últimas décadas (sociólogas, economistas e filósofas feministas, sem mencionar as contribuições de

\footnotetext{
${ }^{2} \mathrm{O}$ conceito de divisão sexual é "a forma da divisão do trabalho social decorrente das relações sociais entre os sexos", que tem como características "a designação prioritária dos homens à esfera produtiva e das mulheres à esfera reprodutiva e, simultaneamente, a apropriação pelos homens das funções de maior valor social" (HIRATA e KERGOAT, 2008, p. 266). Este conceito tem uma concepção sociográfica, de "constatação das desigualdades" (compreensão diferencial de homens e mulheres no mercado de trabalho e nas profissões, variações no tempo e no espaço dessa distribuição e como ela se associa à repartição desigual do trabalho doméstico entre os sexos) e uma acepção, à qual se subscrevem as autoras, de caráter analítico (que mostra o caráter sistemático das desigualdades e articula a descrição do real com uma reflexão sobre como processos sociais de diferenciação hierarquizam as atividades e portanto os sexos - e criam um sistema de gênero) (HIRATA e KERGOAT, 2008, p. 263). No debate francês que dá origem ao conceito, a divisão sexual do trabalho é entendida como o desafio central das relações sociais de sexo.
}

Temáticas, Campinas, 26, (52): 247-284, ago./dez. 2018 
movimentos feministas) sustentando a indissociabilidade entre as análises sobre o trabalho assalariado e reprodutivo e incorporando na análise os fluxos migratórios de mulheres do sul para o norte global para a realização destes trabalhos (CARRASCO, 1999; SASSEN,1991; FALQUET, HIRATA, KERGOAT et al, 2010).

A esse respeito, vale mencionar as análises que Falquet (2016) desenvolve com base em Guillaumin (1992[1978]) sobre o conjunto das mulheres estarem, no capitalismo, submetidas não somente às relações de exploração, mas também de apropriação de seu "corpo-máquinatrabalho". Essa perspectiva parece ter pontos de convergência com a reflexões de Frederici (2017) sobre as formas de acumulação primitiva do capitalismo se manifestarem por meio da apropriação não somente de terras, mas do corpo e trabalho (apropriado e ocultado) das mulheres - formas estas que, sob o capitalismo, inaugurariam um "patriarcado do salário" (FREDERICI, 2017, p. 193-198).

Harvey (2008) salienta que a fase neoliberal de acumulação capitalista recupera, justamente, os mecanismos de espoliação de sua acumulação originária, assim como já pontuava Lipietz (1989) que a conformação de uma nova divisão internacional do trabalho recupera mecanismos da acumulação primitiva capitalista nos processos de constituição de um "fordismo periférico" e "taylorismo primitivo". Considero possível concatenar esses argumentos com o de Frederici (2017) e Falquet (2013, 2016) para pensar sobre a caracterização de um novo neoliberalismo, que recupera mecanismos antigos de espoliação, que seriam desde então já sexuados, para renovar os modos de acumulação capitalista.

Proponho então neste artigo desenvolver, principalmente com base em Hirata (1994, 2001, 2015), Elson (2010), Falquet (2013), Pun (2006) e em pesquisas que tenho desenvolvido (LAPA, 2014, 2016a, 2016b), contribuições para uma reflexão sobre a divisão sexual do trabalho inserida nesse cenário de reconfigurações neoliberais das formas de exploração e apropriação do trabalho. Procurarei apresentar reflexões sobre o uso estratégico da força de trabalho feminina nos processos de internacionalização produtiva, explorando o caso da indústria eletroeletrônica. 


\section{CADEIAS GLOBAIS DE VALOR: VISIBILIZAR TRABALHADORAS/ES}

Observar a dinâmica produtiva e as formas do trabalho no contexto atual é enfrentar, inevitavelmente, a problemática da internacionalização da produção e da reprodução decorrente dos processos de globalização ${ }^{3}$. A análise da produção global e do comércio internacional nas últimas décadas foi marcada pelo uso do conceito de cadeias globais, seja de produção, seja de valor e, mais recentemente, pela ideia de redes globais de valor conceitos elaborados na busca de ferramentas explicativas para dar conta da complexidade dos processos produtivos globais e das inter-relações entre empresas, governo e contexto social que constituem esses processos (DUARTE e SALAS, 2017; SARTI e HIRATUKA, 2018).

Esse debate prescinde tratar tanto das orientações econômicas que guiam os processos de globalização como colocar em evidência os/as trabalhadores/as não apenas como "afetados/as", mas sim como um pilar que sustenta, através de sua força de trabalho explorada/apropriada, as dinâmicas de produção de valor cujos fluxos se internacionalizam.

Há algum tempo vêm sendo analisadas as tendências de conformação de uma divisão internacional do trabalho que "concentra cada vez mais nos países ditos 'subdesenvolvidos' ou 'semi-industrializados' as atividades labour-intensive" (HIRATA, 1994, p. 137). Tal processo de fragmentação das atividades produtivas, em primeiro momento exteriorizadas, depois levadas para fora dos países de capitalismo central, em especial dos EUA, foi iniciado, de acordo com Duarte e Salas (2017) no setor de confecções, englobou em seguida a indústria de eletrônicos, de produção de sapatos e de brinquedos e, em período recente, tem englobado setores de serviços

\footnotetext{
${ }^{3}$ Vale pontuar que o uso do conceito globalização ao longo deste artigo é acompanhado de uma visão crítica, que reconhece o caráter ideológico deste conceito sobretudo nos anos 1990, mais visto como sinônimo positivo de "rompimento de fronteiras" e que por vezes era o termo "neutro" utilizado no lugar de neoliberalismo. O conceito foi criticado por economistas como Chesnais $(1995,1996)$, que adotou, em seu lugar, o conceito de mundialização. Como analisa Klagsbrunn (2008), Chesnais ressalta em seus primeiros estudos que a mundialização é do capital, e que este é o responsável pela mundialização da economia. Eis uma de suas formulações mais precisas a respeito: "o conteúdo efetivo da globalização é dado, não pela mundialização das trocas, mas pela mundialização das operações do capital, em suas formas tanto industrial quando financeira” (CHESNAIS, 1995, p. 4 apud KLAGSBRUNN, 2008, p. 28).
} 
como os call centers, contabilidade e outros. Esse processo de deslocamento produtivo foi encabeçado por empresas transnacionais e levou à criação ou consolidação de atividades industriais nos países que receberam os novos investimentos.

Duarte e Salas (2017) apontam que o processo de externalização das atividades não é um fenômeno novo no capitalismo: a onda anterior mais recente havia sido a do chamado "enxugamento das empresas" nos anos 1980 e 1990 - "um processo duplo de fusões e aquisições, seguido de uma redução da planta de trabalho". Duarte e Salas (2017) pontuam ainda que a terceirização, com seus altos e baixos, acompanha a história do capitalismo e situam a situação atual de ofensiva dos grupos capitalistas para impor os custos de recuperação e saída da crise sobre os trabalhadores como mais um capítulo da permanente disputa entre capital e trabalho, no qual a terceirização desempenha um papel central. Ademais, analisam que na história recente, as terceirizações são um processo que vem acompanhado pelo deslocamento geográfico da produção e dos serviços e pela consolidação de redes econômicas, as chamadas cadeias de produção ou de valor.

Os países sobretudo do Sudeste Asiático, Europa do Leste e América Latina se tornam, especialmente desde os anos 1990, territórios receptores de empresas sobretudo estadunidenses e da Europa central, mas também com forte e cada vez mais significativo papel da China, que crescentemente externalizam partes de seu processo produtivo, o que significa ao mesmo tempo uma fase de industrialização dos países receptores por meio de instalação de transnacionais (que pode ter como consequência, como foi o caso do Brasil, a destruição de parte da capacidade de produção a partir de empresas nacionais) e ao mesmo tempo um processo de consolidação desta divisão internacional do trabalho que separa concepção e execução, isto é, lhes confere eminentemente o papel de manufatureiras de produtos sem ou com pouco valor agregado, já que o desenvolvimento tecnológico fica concentrado nos países de origem das empresas.

Desenvolveu-se, assim, nas últimas três décadas, um intenso processo de internacionalização financeira, produtiva e comercial que provocou a adoção de 
estratégias corporativas de desverticalização, terceirização e fragmentação do processo produtivo e o deslocamento de parte da produção industrial dos países avançados em direção a algumas regiões periféricas e resultou na construção de redes globais e regionais de produção e de fornecimento em diversos setores industriais que integraram países e empresas, com participações nas diferentes etapas das cadeias de valor sob a coordenação das grandes corporações globais (SARTI, HIRATUKA, 2018, p. 129).

Porém, enquanto algumas economias periféricas conseguiram uma inserção virtuosa (Coreia do Sul, China, Taiwan e Índia), outras mantêm uma inserção subordinada (países latino-americanos e do Leste Europeu) (SARTI e HIRATUKA, 2018, p. 130).

Duarte e Salas (2017) salientam que o exame das cadeias globais em geral não insere o trabalho como parte relevante. Um meio de inserir o trabalho no centro dessas análises seria justamente recuperar "a ideia de que tais cadeias são formadas muitas vezes a partir de processos de terceirização e deslocamento produtivo". A construção e manutenção das redes econômicas que se conformam a partir do comércio internacional e da produção através das cadeias globais (e, às vezes, locais) são um processo que envolve apenas as empresas, mas também "os trabalhadores e o contexto institucional de cada país ou região que participa nestes processos" (DUARTE E SALAS, 2017).

Nesse sentido, é importante salientar a dinâmica de geração de empregos em manufaturas nos países periféricos simultânea ao corte de postos de trabalho nos países centrais como parte desta nova divisão internacional do trabalho:

Com relação à geração de empregos, a manufatura empregava aproximadamente 370 milhões de trabalhadores no mundo em 2013, o que corresponde a algo entre $11 \%$ e $12 \%$ da força de trabalho global. Nas últimas décadas, o setor vem destruindo postos de trabalho nos países avançados e criando vagas nos países em desenvolvimento (SARTI e HIRATUKA, 2018, p. 134). 
Uma perspectiva de análise que leva em conta as cadeias de valor, deste modo, revela a importância de um olhar sistêmico sobre o trabalho e quem trabalha. Esse olhar sistêmico, segundo Leite, (2005, p.208), significa, por exemplo, que a compreensão sobre o que acontece em uma empresa (reestruturações, impactos sobre trabalhadores) apenas é possível situando-a no conjunto das dinâmicas econômicas da cadeia produtiva. Ademais, tal olhar sistêmico permite uma análise que não uniformiza trabalhadores de um mesmo setor, já que ao longo de diferentes pontos da cadeia produtiva são verificáveis formas tanto de enriquecimento como de precarização do trabalho e uma diferenciação entre contratantes e terceirizadas, no que se refere a salários, qualificação do trabalho e incidência de doenças profissionais (LEITE, 2005, p. 209).

Essa invisibilidade de trabalhadores no debate das cadeias produtivas se agudiza quando se leva em consideração a divisão sexual do trabalho. Pesquisas como as de Leite (2003) e de Abramo (2005) vêm evidenciando que as mulheres são minoritárias nas grandes indústrias e sua presença cresce nas pontas das cadeias produtivas, em situações de trabalho em geral mais precárias e pior remuneradas. Mais recentemente, Dunaway (2014), que realiza análises das cadeias globais levando em conta a perspectiva de gênero, reconhece a centralidade das mulheres na produção global e, ao mesmo tempo, o quanto tal abordagem é ainda ausente na maior parte das análises sobre esse tema.

A visibilidade de trabalhadores, sobretudo trabalhadoras, nas pontas das cadeias de valor, por vezes ocorre apenas em situações extremas, decorrentes de péssimas condições de trabalho, como por exemplo os suicídios de trabalhadores na montadora de produtos eletroeletrônicos, Foxconn, instalada na China - fabricante da Apple, HP, Sony entre outras ${ }^{4}$. Outro exemplo que põe em evidência o trabalho como um pilar de sustentação de cadeias de valor é caso do desabamento, em 2013, do edifício Rana Plaza em Bangladesh, que abrigava fábricas têxteis fornecedoras de

\footnotetext{
${ }^{4}$ Entre 2010 e 2011, houve 18 tentativas de suicídio na fábrica registradas junto às autoridades, dentre as quais 14 concretizações, mas há relatos também de que também "em 2012 cerca de 150 funcionários da empresa se reuniram no telhado da fábrica e ameaçaram se jogar em um suicídio coletivo caso as condições de trabalho não melhorassem” (FARINACCIO, 2017).
} 
roupas para marcas ou varejistas como Benneton, Carrefour, Primark e Wall Mart 5 .

Ambas situações têm em comum o trabalho em empresas cujas marcas são de países centrais, mas externalizado à países asiáticos com condições de produção consideradas favoráveis ao capital, mas totalmente precárias, degradantes e desumanas para trabalhadores/as. Elas evidenciam não somente o lado obscuro de como se produz uma série de artigos de uso corrente no mundo, mas que é sob a base da extração de mais valia do trabalho que continua gerando o valor que circula nestes fluxos econômicos internacionais. Esses dois setores, de confecções e eletroeletrônico podem, deste modo, ser considerados importantes pontos de observação desta dinâmica de conformação das cadeias globais de valor. Inclusive, as referidas situações extremas devem ser olhadas com atenção uma vez que, em nome da "competitividade internacional", há uma tendência de extensão de tais padrões degradantes de trabalho aos demais países ${ }^{6}$.

\section{O QUE SIGNIFICA ANALISAR A DIVISÃO SEXUAL DO TRABALHO SOB O CONTEXTO NEOLIBERAL?}

Hirata (2001, p. 141), que utiliza o conceito de globalização de forma acompanhada a uma crítica sobre seu uso neoliberal enquanto um modelo normativo que consagra a ordem estabelecida de forma fatalista, afirma que o que haveria em comum entre economistas na definição do fenômeno é a ideia de integração crescente dos mercados nacionais no sentido de formação de um mercado mundial. Tal integração aguçou a heterogeneidade das situações de trabalho, de emprego e de atividade das mulheres e homens do sul e do norte globais. Falquet, Hirata e Kergoat (2010) trazem como

\footnotetext{
${ }^{5}$ A queda do prédio, que não oferecia condições de segurança, resultou na morte quase 1200 trabalhadores e mais centenas de feridos (TEITEBAUM, 2013), dos quais 80\% eram mulheres - o que mostra a dimensão de gênero ligada a estes processos internacionais de terceirização (HIRATA, 2015, p. 13).

"Sarti e Hiratuka (2018, p. 137) caracterizam ter havido um processo de "chinalização industrial" que reforçou as vantagens de custo advindas das economias de escala e escopo e da utilização de um enorme contingente de força de trabalho com baixos salários (sobretudo em setores de processos discretos, como os de eletrônica e vestuário), o que promoveu o acirramento da competição no mercado internacional.
}

Temáticas, Campinas, 26, (52): 247-284, ago./dez. 2018 
tese central que o gênero é um organizador chave da globalização, o que significa que o modo societário neoliberal (e suas dinâmicas de classe, de raça, seus movimentos migratórios) é sexuado.

Hirata (2015, p. 16-17) apresenta quatro consequências da globalização sobre a divisão sexual do trabalho: 1) a de que a globalização criou mais empregos femininos que são, contudo, empregos mais precários e vulneráveis ${ }^{7}$; 2) a abertura de mercados e a política de desregulamentação implicaram em condições de trabalho desfavoráveis para as mulheres, aumentando a carga de trabalho remunerado e não remunerado; 3) parte do trabalho de reprodução social assegurada antes pelo Estado passa a ser remetida à esfera familiar e ao mercado de trabalho precário (trabalho feminino pouco remunerado para assegurar o trabalho de reprodução social); 4) há aumento das desigualdades de sexo, de classe, de raça, pela reorganização da divisão mundial do trabalho e de acesso aos recursos, mas também há processos de inovação política, como a aparição de movimentos sociais de mulheres contra a globalização neoliberal, a exemplo da Marcha Mundial de Mulheres.

Sassen (1991) analisa o papel de migrantes para realizar o trabalho de reprodução social para casais de elite em cidades globais como parte de "novos circuitos de globalização" e de "mobilização por baixo". Falquet (2013, p. 18) situa esta análise de Sassen como a primeira entre várias que se dedicaram a investigar tal processo migratório de mulheres para realizar o trabalho de reprodução social nos países centrais (cuidados e educação das crianças, das pessoas idosas e dos doentes, manutenção material dos lares, dos lugares de estudo, de trabalho e de vida social).

Afirma Falquet (2013, p.19) que o "trabalho desvalorizado" ou

\footnotetext{
${ }^{7}$ Uma das mais importantes consequências dessa evolução da atividade feminina em trabalhos precários consiste no fato de que este pode ser um regime por vir de assalariamento masculino e feminino, isto é, traz como horizonte a extensão dos piores padrões de trabalhos para toda a classe trabalhadora (HIRATA, 2001).

${ }^{8}$ Falquet compreende por "trabalho desvalorizado" os que "sobram" para migrantes pois os demais não querem realizar; os trabalhos frutos de um processo inconcluso de "proletarização", que não teriam alcançado o estatuto de liberados de relações de apropriação, e o acesso parcial e truncado ao assalariamento que obriga as mulheres a buscar um complemento em outra parte (FALQUET, 2013, p. 19).
} 
"trabalho considerado como feminino" é "uma das tendências que se desenvolve com a globalização neoliberal" e "é exercido majoritariamente por mulheres, inclusive brancas, mas também por pessoas racializadas e proletarizadas, inclusive homens. Ele permite, assim, estabelecer o vínculo entre as relações sociais de sexo, 'raça' e classe, viabilizando entrever a dinâmica da reorganização neoliberal dessas relações”.

Com base na observação destes trabalhos considerados femininos e desvalorizados como lócus de análise privilegiado, Falquet desenvolve uma teoria segundo a qual a reorganização neoliberal das relações de sexo, classe e raça se dá sob a lógica de vasos comunicantes (FALQUET, 2013, p.19). Segundo tal teoria, que se assenta sobre acúmulos do feminismo materialista francês, estão em constante reequilíbrio os diferentes modos de obtenção do trabalho: exploração, apropriação individual, apropriação coletiva. E as relações sociais de sexo raça e classe, em sua dinâmica, se assentam diferentemente, ao longo da história, sobre os patamares destas formas de obtenção do trabalho.

Falquet exemplifica ao afirmar que as relações de sexo e de raça, ambas organizadas em torno da apropriação - por meio da sexagem e da escravidão - "se reforçam ou se enfraquecem à medida que a apropriação evolui para a exploração (ou seja, as relações de classe) ou se afasta dela" (FALQUET, 2013, p.19). O que é interessante, no sentido de renovação no argumento, são as consequências deste processo de reorganização neoliberal de relações de sexo raça e classe por meio de vasos comunicantes apresentados por Falquet:

(1) nunca nenhuma das relações desaparece totalmente; (2) mesmo que se pense poder modificar apenas uma por vez, sua transformação afeta forçosamente as outras e (3) todas as transformações são reversíveis, o que nem Marx, nem Balibar e Wallerstein, nem Guillaumin haviam considerado explicitamente (FALQUET, 2013, p.19).

\footnotetext{
9 Falquet (2013, p. 18) denomina de "trabalho considerado feminino" o continuum entre as atividades de babás, diaristas, mulheres em situação de prostituição, assim como as transições entre casamento e assalariamento. Segundo esta autora, tal denominação permite abordar o trabalho de reprodução social em sua transição entre seu caráter mais ou menos assalariado e, assim, entre as lógicas de apropriação e exploração.
}

Temáticas, Campinas, 26, (52): 247-284, ago./dez. 2018 
Sua tese reforça as concepções imbricacionistas das relações sociais ao mesmo tempo em que reforça a historicidade como elemento fundamental para se compreender as transformações na divisão sexual do trabalho: os avanços não são plenos nem irreversíveis, muito menos são isoláveis das demais relações sociais, como as de raça e a de classe. Saliento então que o argumento central de Falquet (2013, p. 23) reside justamente em afirmar que "o capitalismo neoliberal, longe de libertar as mulheres, reorganiza simplesmente o equilíbrio entre apropriação e exploração, segundo uma lógica de vasos comunicantes".

A análise de Falquet (2013, p. 18) enfatiza que "a contribuição das mulheres através de seu deslocamento crescente (nacional e internacional) para realizar o trabalho de reprodução social parece constituir um elemento central da globalização neoliberal". O papel do trabalho em serviços é de fato crucial, dado seu caráter crescente em escala global e a predominância feminina nos fluxos migratórios para sua realização, a qual Falquet, Hirata e Lautier (2006) já haviam traduzido na fórmula "homens em armas, mulheres em serviços" em análises sobre divisão sexual do trabalho no norte e sul globais.

Uma dimensão talvez menos aprofundada na literatura geral sobre a reconfiguração da divisão sexual do trabalho sob a globalização neoliberal é a dos trabalhos realizados não pelas mulheres que migram para os países centrais, mas daquelas que permanecem nos países periféricos e que são integradas às redes econômicas globais por decorrência dos processos de externalização da produção dos países centrais rumo aos periféricos.

Os chamados "novos países industrializados" (NPI) se inserem neste tipo de regime global de formas diferenciadas mas o que teria sido característico dos denominados NPI é a presença, no interior desses regimes, da estratégia que se denominou de "substituição de exportações"; essa decisão de romper com o modelo primário-exportador, pelo desenvolvimento da exportação de bens manufaturados, nas atividades do Departamento III (atividades de mão-de-obra "banalizada") da tripartição fordista. (LIPIETZ, 1989, p. 315). Esta estratégia pode se articular com o regime de acumulação local, central e com os regimes de acumulação do restante da periferia de diversas formas e Lipietz destaca duas como 
especialmente significativas: a "taylorização primitiva" e o "fordismo periférico".

Como exemplos para a taylorização primitiva estariam as experiências de deslocalização rumo a países com elevadas taxas de exploração (salário, duração e intensidade do trabalho) e reexportação dos produtos para países centrais, a exemplo de, nos anos 60 e 70, da externalização essencialmente têxtil e eletrônica a regiões como zonas francas da Coréia e de Formosa e também a Singapura e Hong Kong. Nas situações de taylorização primitiva, o que são deslocalizados consistem em verdadeiras "indústrias de mão de obra" caracterizadas por postos de trabalho parcelados e repetitivos, não ligados por um sistema automático de máquinas, mas eminentemente por equipamentos leves e individuais.

O sexo do trabalhador a ser convertido em mão de obra taylorizável não é indiferente, sendo reconhecido por Lipietz que existe uma utilização de trabalho eminentemente feminino:

É claro que é sempre necessário encontrar a mão-de-obra taylorizável. Ora, ela existe. Pois a classe operária não é a única depositária inicial do savoir-faire, em função de sua relação com a produção material. Desde a aurora do patriarcado (a coisa mais compartilhada no mundo), as mulheres, exploradas e adaptadas à produção doméstica, estão submetidas à dupla exigência das induistrias taylorizadas: ausência total de iniciativa quanto aos fins do trabalho e exigência total de atenção na realização desse trabalho, $e$ isso em atividades muito próximas - no que se refere aos gestos concretos (tais como a fabricação de cestos ou a tecelagem) - àquelas de dois ramos vedetes da "deslocalização": o têxtil e a montagem eletrônica ${ }^{10}$ (LIPIETZ, 1989, p. 316).

Importante observar a análise do autor sobre esta mão de obra feminina como também dotada de um tipo específico de savoirfaire derivado de sua experiência na produção doméstica - a ausência de iniciativa (ou poderíamos dizer de autonomia) no trabalho e uma capacidade atentiva

${ }^{10}$ Grifo nosso.

Temáticas, Campinas, 26, (52): 247-284, ago./dez. 2018 
na realização das operações - que vem dos trabalhos que já realizavam e é mobilizada para os trabalhos que passam a realizar, nas pontas externalizadas das cadeias globais de produção ${ }^{11}$.

Lipietz (1989, p. 316) associa esta estratégia de taylorização primitiva à de acumulação primitiva na Europa, uma vez que permite uma elevação sensível da taxa de mais valia por meio de uma extorsão máxima, "sanguinária", de uma mão de obra que mal tem condições de reprodução regular. Lipietz aproxima estes mecanismos de obtenção de mais valia à caracterização de Marx das "leis sanguinárias" que possibilizaram o início da acumulação primitiva na Inglaterra, afirmando ser possível caracterizar frequentemente a produção deslocalizada nestes países periféricos de "taylorização sanguinária".

Com relação ao que Lipietz (1989, p. 317) denomina de fordismo periférico, surge em certos países dos anos 70 a partir da "conjunção de um capital local autônomo, de classes médias urbanas relativamente abundantes e de embriões significativos de uma classe operária com experiência". O rumo desta experiência de fordismo periférico parte de escolhas de caráter político associadas a lutas de classes internas em Estados como Coréia, México, Brasil, Espanha, Polônia, cada país a seu modo. A utilização do conceito de "fordismo periférico" se dá sob o argumento de que embora trate-se de um fordismo autêntico no sentido de possuir processos de mecanização e uma associação da acumulação intensiva com o crescimento de mercados de bens de consumo duráveis, a técnica e organização do trabalho assim como o mercado consumidor assumem características peculiares diferentes do fordismo central ${ }^{12}$.

${ }^{11}$ Esta característica de uso do trabalho feminino como "taylorizável vem se confirmando em pesquisas recentes justamente nos setores apontados pelo autor, o têxtil e de montagem eletrônica, inclusive no Brasil (LAPA, 2014; LEITE, SILVA e GUIMARÃES, 2017).

${ }^{12} \mathrm{O}$ fordismo "continua sendo periférico, antes de mais nada no sentido de que, nos circuitos mundiais dos ramos produtivos, os postos de trabalho e a produção correspondendo aos níveis de fabricação qualificada e, sobretudo, de engenharia permanecem largamente exteriores a esses países. Por outro lado, os mercados correspondem a uma combinação específica do consumo das classes médias modernas locais, com acesso parcial dos operários do setor fordista aos bens duráveis das famílias, e das exportações desses mesmos produtos manufaturados de baixo preço para o centro. Assim, o crescimento da demanda social (que é uma demanda 
A "abertura" para a "primeira periferia" corresponde à busca de salários mais baixos e ampliar o mercado para os países centrais, instalando-se nos países protegidos por barreiras alfandegárias. Sob certos aspectos, trata-se apenas do desenvolvimento de um mecanismo inerente ao fordismo: o desenvolvimento de "circuitos de ramos " em "bacias" de mão-de-obra desigualmente qualificada, sindicalizada e remunerada. (LIPIETZ, 1989, p. 313).

Do ponto de vista do processo de trabalho, o fordismo caracterizase por uma tripartição das atividades em três níveis: a concepção, a produção qualificada e a execução e montagem desqualificadas, não exigindo, em princípio, qualquer qualificação. A possibilidade de separar geograficamente estes três níveis implica na oportunidade, para o capital, da busca não apenas de mão de obra em condições de qualificação e de exploração diferenciadas, mas da proximidade aos grandes mercados e esta é a base da do desenvolvimento da nova divisão internacional do trabalho (LIPIETZ, 1989, p. 326).

Esta gradação entre níveis de qualificação dentro dos ramos industriais se sobrepõe à divisão horizontal do trabalho e constitui "uma forma de ampliação-reorganização do próprio regime de acumulação e não a forma da relação entre este último e seu "exterior" (LIPIETZ, 1989, p. 314).

Lipietz tem, contudo, o cuidado de observar que no interior de cada país que ele enquadra como NPI (Novos Países Industrializados) combinam-se as estratégias e as lógicas mais diversas e que existe uma influência da divisão sexual do trabalho na constituição desta combinação de estratégias dentro de um mesmo país: "a divisão sexual do trabalho permite, frequentemente, a coexistência da taylorização primitiva (as mulheres na eletrônica e no têxtil) e do 'fordismo periférico' (os homens na indústria automobilística) ${ }^{13}$ ", (LIPIETZ, 1989, p. 327).

social mundial), especialmente pelos bens duráveis das famílias, é certamente antecipado, ainda que não seja institucionalmente regulado em uma base nacional, em função dos ganhos de produtividade dos ramos fordistas locais" (LIPIETZ, 1989, p. 317).

${ }^{13}$ Grifo nosso. 
Harvey (2008) analisa que os efeitos da neoliberalização não são indistintos sobre a classe trabalhadora e incorpora em sua análise da acumulação por espoliação alguns dos mecanismos que se sustentam na agudização da subordinação social das mulheres:

A acumulação por espoliação tipicamente solapa todos os poderes que as mulheres possam ter tido nos sistemas de produção/comercialização domésticos e no âmbito de estruturas sociais tradicionais e reposiciona tudo em mercados de mercadorias e de crédito dominados por homens. Os caminhos da libertação das mulheres de controles patriarcais tradicionais em países em desenvolvimento passam ou pelo trabalho fabril degradante ou pela comercialização da sexualidade (HARVEY, 2008, p. 183).

A análise de Harvey é importante ao reconhecer o que está em jogo para as mulheres no atual contexto neoliberal. Dentre os elementos pontuados, importante destacar o equívoco que seria crer serem "liberdades" frente aos controles patriarcais tradicionais as condições degradantes do trabalho fabril ou a comercialização da sexualidade.

Um exemplo significativo é o dado por Pun (2006) a respeito das trabalhadoras chinesas que migram de pequenas cidades onde realizavam o trabalho agrícola e tinham como destino, ali, o casamento, para realizarem o trabalho fabril em cidades, contratadas não só por serem migrantes rurais, mas por serem mulheres. Aparentemente o trabalho nas fábricas lhes proporcionaria liberdade frente ao controle patriarcal que as destinava ao casamento, mas em realidade elas acabam tendo dois ao invés de apenas um caminho permeado de subjugações a trilhar: casamento ou trabalho fabril.

De todo modo, boa parte delas é absorvida como força de trabalho urbana e fabril que passa a integrar a dinâmica internacional de produção. Renova-se assim o contingente de trabalhadoras proletarizadas sob o que Lipietz (1989) nomina de "taylorismo primitivo", submetido a novas 
relações de exploração e apropriação. Conforma-se uma nova composição de classe trabalhadora, com maior participação das mulheres no trabalho fabril, se comparada ao período fordista.

Pun (2006, p. 15) enfatiza que o capitalismo "não tem interesse em um corpo genérico, mas está interessado em um corpo particular, o feminino, que é imaginado como mais obediente, tolerante e conformado com a máquina fabril" ${ }^{14}$. Por esta razão, esta autora afirma que para além da importância da divisão entre campo e cidade pensada por Marx como base para a acumulação do capital, a diferença sexual figura também como requisito, "especialmente na era da manufatura global" (PUN, 2006, p. 15).

Vale salientar que este processo de internacionalização da produção não tira vantagens do trabalho feminino apenas por meio das relações de exploração direta de sua força de trabalho, mas vem recorrendo à espoliação e apropriação: a instalação de empresas transnacionais nos países periféricos tem como critério se estabelecer em locais onde não precisem pagar muitos impostos, em geral reduzidos como condição para a instalação de plantas fabris, o que tende a produzir uma queda no financiamento da saúde, educação, assistência, infraestrutura e entretenimento públicos que "reduzem o trabalho remunerado necessário à reprodução social” (ELSON, 2010, p. 68) ${ }^{15}$.

Isso significa que nestes países receptores de empresas transnacionais, não são somente as políticas diretas de austeridade praticadas pelo Estado que reduzem as políticas sociais, mas também as vantagens tributárias concedidas às empresas, que têm como consequência espoliar o orçamento público, provocando uma fragilização das condições de reprodução da força de trabalho - o que tende a impactar significativamente as mulheres, por meio do aumento de sua carga total de trabalho, já que são designadas prioritariamente ao trabalho de reprodução social e que dele precisam se encarregar sobretudo quando empobrecidas e sem a adequada oferta dos serviços públicos.

Esta situação demonstra um dos princípios do neoliberalismo de promover "redistribuições" de capital por meio de políticas do Estado

\footnotetext{
${ }^{14}$ Tradução livre nossa.

${ }^{15}$ As referências a esta autora no texto têm tradução livre nossa.
} 
cujo fluxo vem das classes dominadas para as dominantes (HARVEY, 2008, p. 177), a exemplo desta diminuição de impostos para empresas que desfinancia os serviços públicos essenciais para a classe trabalhadora. Demonstra, também, o princípio da coprodução entre as dimensões do trabalho assalariado e reprodutivo (KERGOAT, 2010), fundamental na para a compreensão das dinâmicas da divisão sexual do trabalho.

\section{A DIVISÃo SEXUAL DO TRABALHO ASSALARIADO SOB O NEOLIBERALISMO: ALGUNS EXEMPLOS}

De acordo com Lobo (2011), a definição do "melhor trabalhador", um dos pressupostos da "gestão científica" do trabalho, significa exprimir os critérios que diferenciam os trabalhos assalariados de homens e mulheres. Como desenvolvi anteriormente (LAPA, 2014, 2016a), uma das maiores contribuições da teoria feminista à teoria do processo de trabalho - que se dedica, entre outras coisas, a compreender os processos de controle dos trabalhadores e as qualificações requeridas e reconhecidas ou não no trabalho - foi a de postular haver uma construção social da qualificação das trabalhadoras, qualificação esta cuja origem não se restringe ao ambiente de trabalho remunerado (aprendizado "on the job") ou aos canais de qualificação formais, como instituições de ensino.

As economistas inglesas Diane Elson e Ruth Pearson e a socióloga francesa Danièle Kergoat desenvolveram no início dos anos 1980, em paralelo, teses convergentes quanto ao papel do trabalho reprodutivo designado prioritariamente às mulheres na formação do trabalho feminino como uma força de trabalho adequada para empregos assalariados sobretudo na indústria manufatureira, que requerem habilidades como minúcia, destreza, rapidez e paciência (ELSON e PEARSON, 1981; KERGOAT, 1984), colocando em questão que o trabalho destas mulheres fosse desqualificado, mas sim dotado de uma qualificação adquirida socialmente - e não reconhecida - por meio do "treino" proporcionado pelo trabalho doméstico.

Tal situação verificou-se em pesquisa (LAPA, 2014, p. 157): ao analisar as trajetórias laborais precedentes das operárias do setor 
eletroeletrônico, parte delas havia atuado como trabalhadora doméstica, cuja atividade possibilita um treino "nas habilidades como destreza, paciência, minúcia, entre outros requeridos especialmente nos trabalhos mais manuais do setor eletroeletrônico (LAPA, 2014, p. 157). Isso sem mencionar o trabalho doméstico não remunerado que é realizado pelas trabalhadoras em suas próprias casas.

Estes argumentos sobre a construção das habilidades/qualificações da força de trabalho fabril feminina trazem reflexões basilares para se pensar esta escolha do "melhor trabalhador" no contexto de globalização. É neste sentido que, recentemente, a economista Elson (2010) sustenta e reivindica os debates econômicos heterodoxos que reconhecem que a busca de vantagens comparativas no comércio internacional pelas empresas é um processo sexuado.

Segundo esta autora, para quem "as relações sociais de sexo impregnam toda a vida econômica, e as economias são todas estruturas sexuadas" (ELSON, 2010, p. 59),

o recurso ao mecanismo de gênero nos permite perceber

a criação de uma vantagem comparativa na realização do desenvolvimento desigual como os processos que se desenvolvem através de instituições sexuadas. Analisando os resultados, a economia feminista ultrapassa critérios sustentados na expansão dos empregos, dos salários e no consumo pessoal, para considerar as condições de trabalho e a carga global de trabalho remunerado ou não (ELSON, 2010, p. 60).

As contribuições de Elson são de significativa relevância ao fornecer elementos para a compreensão das dinâmicas conjugadas de divisão sexual e internacional do trabalho, levando em consideração uma concepção ampliada de trabalho que engloba o pago e o não pago - um dos princípios partilhados por teóricas da economia feminista.

O caráter significativo de sua contribuição reside justamente em desenvolver os dois aspectos desta concepção de trabalho, remunerado 
ou não, sob as teias e interesses do comércio internacional. Afirma Elson (2010, p. 58) que as responsabilidades atribuídas às mulheres em matéria de reprodução social têm um impacto sobre sua posição no emprego: sua taxa de atividade é inferior à dos homens, embora esta distância recentemente se atenue. As mulheres têm uma tendência a acumular uma carga global de trabalho mais pesada ${ }^{16}$.

Elson (2010, p. 58) mostra que no conjunto dos países as mulheres predominam nas indústrias de manufatura em setores de baixa tecnologia para a produção de bens competitivos, enquanto concentra os homens nos setores de média e alta tecnologia, sendo que "as indústrias manufatureiras feminizadas oferecem geralmente remunerações inferiores e possuem um status social inferior, não somente justificada por diferentes níveis de formação e educação, mas também em razão de discriminações diversas" "17.

Elson (2010, p. 64) pontua o papel que países do sul global e países semi-industrializados de forma geral cumprem no contexto mundial por oferecerem a vantagem competitiva de tecnologias modernas de transporte e comercialização com disponibilidade de mão de obra com bons preços - processo dentro do qual o emprego feminino é fortemente requerido, embora volúvel, também, a processos de demissão em massa de acordo com as flutuações de mercado que tornem a produção nestes países desvantajosas ${ }^{18}$.

Harvey (2008, pp. 181-182) é um dos autores que traz a análise que reconhece que as diferenciações no interior da classe trabalhadora, inclusas as de gênero, são utilizadas como mecanismos de gestão na busca

\footnotetext{
${ }^{16}$ No Brasil, as pesquisas de uso do tempo (PNAD/IBGE) mostram que considerados os períodos de trabalho remunerado e doméstico, as mulheres trabalham mais de 57 horas, enquanto homens trabalham pouco mais de 50 (HIRATA, 2015, p. 16).

${ }^{17}$ Além disso, as mulheres estão mais frequentemente que os homens em empregos informais e sem proteção social, em empresas menores e encarando mais dificuldade para alcançar negócios mais rentáveis. No setor agrícola, a concentração de mulheres em atividades não reconhecidas e com ganhos inferiores aos dos homens leva Elson (2010, p. 59) a afirmar que "no trabalho assalariado do agronegócio, encontra-se as mesmas desigualdades de sexo que no setor manufatureiro".

${ }^{18}$ A exemplo do fechamento, em 2016 e 2017, de plantas da Foxconn (fabricante taiwanesa de produtos da Apple) instaladas no Brasil.
}

Temáticas, Campinas, 26, (52): 247-284, ago./dez. 2018 
de vantagens para os empregadores: "Surgem então mercados de trabalho segmentados, bem como o frequente uso de distinções de raça, etnia, gênero e religião, declaradamente ou de modo encoberto, de maneira que redundam em vantagens para os empregadores".

Um exemplo de busca de vantagens competitivas que que recorre ao baixo custo da força de trabalho (sobretudo feminina) é o setor eletroeletrônico que manufatura produtos de informática e telecomunicações. As indústrias eletroeletrônicas transnacionais instaladas no Brasil se caracterizam por pouco desenvolverem tecnologia nacionalmente, por pouco permitirem a transferência de tecnologia das matrizes, além de fundamentalmente não produzirem componentes no país. Ademais, a estruturação do setor se assenta no uso da força de trabalho feminina desde o início, sendo este o setor industrial que pior remunera $e$ mais emprega mulheres na indústria metalúrgica brasileira ${ }^{19}$. Estes elementos levam à reflexão sobre as razões da elevada rentabilidade deste negócio para estas empresas: trata-se de uma combinação da apropriação da força de trabalho de um país periférico ou "em desenvolvimento", feminina e mal remunerada $a^{20}$, com condições favoráveis de produção e circulação

${ }^{19}$ No Brasil, a força de trabalho feminina é minoritária na indústria metalúrgica (18\%), mas dentre os diversos setores que a compõem (automotivo, eletroeletrônico, naval, aeroespacial e defesa, bens de capital, siderurgia e metalurgia básica, outros materiais de transportes), a participação feminina é mais significativa no de eletroeletrônicos, no qual mulheres representam $34,5 \%$ da força de trabalho. É justamente nesse setor com maior participação de trabalhadoras que se verificam, se comparado com os demais setores metalúrgicos, as maiores desigualdades salariais entre homens e mulheres: a diferença salarial por sexo no setor eletroeletrônico é de $36,3 \%$. Para referência, a média dessa diferença na indústria metalúrgica como um todo é de 25,6\% (DIEESE/Subseção CNM-CUT - FEM-CUT/SP, 2017). Uma reflexão sobre a diferença salarial por sexo no setor metalúrgico e sua relação com a segregação setorial das mulheres é encontrada em Lapa (2016b).

${ }^{20} \mathrm{O}$ Brasil tem uma distinção com relação aos demais países para os quais as grandes marcas de produtos eletroeletrônicos externalizam sua produção: nele existem (ainda) direitos trabalhistas e previdenciários consolidados, além de salários que, embora defasados em relação ao custo de vida nacional e os menores entre os praticados dentro do setor metalúrgico brasileiro, são que os praticados, por exemplo, nos países asiáticos (CAMPOS; GOMES; SCHIPPER, 2017). Vale salientar que no Brasil, entre 2004 e 2014, houve uma política de valorização do salário mínimo que minimizou a defasagem dos salários; em contrapartida, empresas eletroeletrônicas recorrem à rotatividade e às terceirizações como estratégia de rebaixamento de mão de obra (LAPA, 2014).

Temáticas, Campinas, 26, (52): 247-284, ago./dez. 2018 
(incentivos fiscais governamentais, amplo mercado consumidor) sem a contrapartida da transferência de tecnologia. Uma situação que somente é possível compreender analiticamente com a combinação das dimensões divisão social, sexual e internacional do trabalho (LAPA, 2014, p. 329).

Uma análise que leva em conta estes movimentos internacionais, de deslocalização produtiva e de busca de vantagens competitivas, leva à conclusão que não existe uma situação passiva das empresas diante das vantagens competitivas, mas que elas influenciam a construção de tais vantagens (o que pode significar, inclusive, barganhas para possibilitar que a força de trabalho se barateie ainda mais, por meio da quebra de proteções trabalhistas). Isso significa, no caso brasileiro (LAPA e LEITE, 2017, p. 327-328), o desdobramento em torno da tendência ao aumento da precarização do trabalho no que concerne ao aumento da instabilidade dos vínculos, rebaixamento do acesso a direitos e benefícios associados ao trabalho e à piora das condições de trabalho, um cenário que afeta predominantemente o trabalho feminino.

Quando se realizam análises sobre as dinâmicas de organização do trabalho em perspectiva sexuada, é possível notar também uma utilização diferenciada da força de trabalho no interior dos próprios espaços laborais. Esta alocação diferencial não é um processo aleatório, mas que se baseia em princípios da divisão sexual do trabalho.

Essa perspectiva sexuada questiona as teorias organizacionais da “especialização flexível”, para as quais, Segundo Jenson (1989, p. 144), os trabalhadores homens são a norma, e "gênero, raça ou nacionalidade entram na análise somente para explicar divergências da norma”, não havendo espaço para a noção de que "mulheres trabalhadoras podem ser a norma em alguns setores ${ }^{21 "}$.

Tal reflexão merece destaque, uma vez que "em situações em que as mulheres são maioria da força de trabalho, como no caso das indústrias eletroeletrônicas, considera-se que o estatuto e condições de trabalho de trabalhadoras podem ser consideradas como "norma" (LAPA, 2014, p. 77). Portanto, a questão de onde as mulheres são colocadas nas análises é crucial.

${ }^{21}$ Grifo nosso.

Temáticas, Campinas, 26, (52): 247-284, ago./dez. 2018 
A inobservação da dimensão de gênero implica, conforme Jenson (1989, p. 155), na "persistência dos efeitos da segmentação sexuada da força de trabalho e da negação da construção social da qualificação". A análise que invisibiliza mulheres resulta, ademais, na ocultação das condições de trabalho de parte significativa da classe trabalhadora de países periféricos que realiza trabalhos não considerados qualificados (LAPA, 2014, p. 79).

Ao incluir a dimensão da divisão sexual do trabalho, mudar o ângulo de análise e incorporar também o trabalho das mulheres dos países periféricos, conforme Hirata (1994, p. 136), é possível apontar um contexto misto de modelos produtivos com dois possíveis "cenários sexuados de flexibilidade": (i) o da coexistência entre setor flexibilizado (masculino) e taylorizado (feminino) e (ii) o cenário no qual setores femininos e masculinos são afetados pela modernização, mas de maneiras diferentes, por exemplo envolvendo reprofissionalização para os homens e formas de emprego atípico para as mulheres.

Ocaso do setor eletroeletrônico no Brasil (LAPA, 2014), é emblemático neste sentido. A montagem de produtos utiliza eminentemente mão de obra feminina: as trabalhadoras predominam significativamente na montagem manual de celulares e tablets e também no reparo de linha, enquanto homens predominam em funções externas à linha como abastecedores, técnicos de manutenção, líderes, operadores das máquinas que realizam etapa de montagem automatizada, entre outros. Além disso, o trabalho é organizado sob métodos mistos que mesclam formas flexíveis de gestão sem abandonar inteiramente os rígidos. $\mathrm{Na}$ prática, as mulheres continuam trabalhando em funções predominantemente taylorizadas, sujeitas a adoecimentos devido ao trabalho manual e repetitivo e com poucas possibilidades de crescimento profissional, mesmo quando mais escolarizadas (algumas trabalhadoras em empresas instaladas no Brasil fazem cursos técnicos e até faculdades, mas relataram sofrerem discriminações nos momentos de receberem promoções pelo fato de serem mulheres).

Contudo, foi possível verificar algumas mudanças na divisão sexual do trabalho: verifica-se a presença, minoritária, de mulheres em cargos anteriormente só masculinos: técnicas, engenheiras, líderes de produção, operadoras de máquinas, inspetoras de qualidade. De outro lado, as 
tentativas de masculinização de linhas de montagem não vingaram e voltou-se a feminizar tais postos. Isso não quer dizer que é impossível que homens façam tais trabalhos, mas só reforça a tese de que as habilidades necessárias para funções que exigem motricidade fina como a montagem de smartphones se forjam no espaço doméstico, cujas funções permanecem sendo atribuídas às mulheres (LAPA, 2014) 22 .

Ademais, existe uma relação intrínseca entre terceirização e uso do trabalho feminino, uma vez que as mulheres estão nas pontas destas cadeias produtivas globais que promovem, dentro dos países, novas terceirizações. Em análise sobre duas transnacionais sul coreanas do setor instaladas no Brasil, foi possível constatar que (i) as terceirizações eram crescentes e tinham como perspectiva a redução de custos (rebaixamento salarial ${ }^{23}$ e de benefícios) e externalização dos conflitos trabalhistas (instalavam-se em cidades fora da representação sindical da empresa terceirizadora); (ii) foram feitas em um período no qual não era permitido legalmente terceirizar atividades-fim ${ }^{24}$, que foram justamente as terceirizadas (montagem e reparo de celulares); (iii) as pequenas empresas para o qual o trabalho era terceirizado tinham fornecimento exclusivo para as contratantes e empregavam majoritariamente trabalho feminino (LAPA, 2014, pp. 131-138).

Considero, assim, haver no setor eletroeletrônico um "cenário no qual as condições técnicas de organização do trabalho se articulam com as características da força de trabalho feminina e favorecem a configuração de formas de apropriação intensiva do trabalho" (LAPA, 2014, p. 193). Isso se explica pelo fato de que divisão sexual desigual do trabalho privilegia a

${ }^{22}$ Vale salientar que os avanços na divisão sexual do trabalho doméstico (i.e., ampliação da participação dos homens) têm sido mais lentos que na divisão do trabalho assalariado nos últimos 20 anos (HIRATA, 2015, p. 15)

${ }^{23}$ Trabalhadoras das terceirizadas ganhavam menos para fazer os mesmos trabalhos realizados na empresa matriz, além de terem, também, maiores jornadas maior instabilidade no emprego (LAPA, 2014).

${ }^{24}$ Isto é, eram terceirizadas as atividades centrais que constituíam a finalidade das empresas, o que à época entrava em desacordo com o previsto no enunciado 331 da Súmula de jurisprudência do TST. Contudo, tal categorização que diferenciava atividades meio de atividades fim e protegia estas últimas de serem indiscriminadamente terceirizadas, foi desconstruída após a aprovação de um projeto de lei, em 2017, que passou a permitir a terceirização irrestrita, o qual teve o aval do Superior Tribunal de Justiça brasileiro em 2018.

Temáticas, Campinas, 26, (52): 247-284, ago./dez. 2018 
predominância de mulheres em postos manuais com trabalhos repetitivos, sob controle intensivo da gerência, pelos ritmos das próprias máquinas/ linhas, pela imposição do fluxo tensionado e ainda sob o paradigma da qualidade total, pressionadas para não errarem, num quadro em que, diante do chamado "modelo de competência" que controla a lealdade das/os trabalhadoras/es, as mulheres são consideradas mais comprometidas com o trabalho (devido à sua sociabilidade extra-trabalho que delas demanda serem as principais responsáveis pelo cuidado e muitas vezes também pelo sustento familiar) (LAPA, 2014, p. 192). Um cenário sobre o trabalho feminino assalariado, como se verifica, cujas dinâmicas se enovelam às do trabalho reprodutivo destas trabalhadoras.

\section{ARMADILHAS DO NEOLIBERALISMO SOBRE O TRABALHO E A AUTONOMIA DAS MULHERES}

Fraser (2009) e Skeggs (2015) estão entre as autoras que vêm analisando haver um processo de cooptação ideológica do feminismo pelo neoliberalismo. Fraser partilha a preocupação de que a crítica feminista ao sexismo, que em outros tempos vislumbrava um processo de emancipação para as mulheres, "esteja agora servindo de justificativa para novas formas de desigualdade e exploração". Ela acredita que o feminismo de segunda onda deu aberturas para uma ambivalência e que a brecha aberta para o desenvolvimento de um feminismo liberal-individualista foi "aproveitada". Os esforços pela libertação feminina passam a ser, então, enredados com os esforços neoliberais para a construção de uma sociedade de livre mercado. Isso trouxe implicações específicas à relação crítica das mulheres com as próprias condições de trabalho sob o capitalismo:

Feministas que certa vez criticaram uma sociedade que promoveria o carreirismo agora aconselham mulheres a o "aceitarem". Um movimento que uma vez priorizou solidariedade social agora celebra empresárias. A perspectiva que certa vez valorizou o "carinho" e a interdependência agora encoraja avanços individuais e meritocracia (FRASER, 2013). 
Neste sentido, é interessante recuperar alguns elementos e construções ideológicas que fizeram parte da ascensão de Margareth Tatcher enquanto figura feminina comandando um processo de espraiamento social do neoliberalismo. Segundo Skeggs ${ }^{25}$ (2015), no marketing político dos anos 1980 Tatcher tinha um discurso midiático que se dirigia diretamente às mulheres através de uma retórica "familista". Ela se apresentava como uma dona de casa e difundia a retórica da maternidade - enquanto o mercado de trabalho se degradava para as mães das classes populares e as mídias não paravam de desacreditar a esquerda enquanto "histérica" em suas políticas antirracistas e anti-sexistas (Tatcher combateu não só as entidades sindicais, mas também as feministas). Durante o seu regime de governo, os valores do individualismo, da meritocracia e do esforço pessoal impregnaram o discurso da cultura das classes populares (SKEGGS, 2015, pp. 279-280).

Tatcher incarnou o que ficou conhecido como "triunfalismo feminino", "a capacidade individual mais do que coletiva de triunfar diante dos outros sem abandonar suas características femininas" (SKEGGS, 2015, p. 179). Este peso colocado pelo "tatcherismo" sobre os valores maternais especiais e a existência de uma virtuosidade feminina contra uma maldade masculina nutriu o que ficou conhecido como "novo feminismo". A passagem de uma visão de direitos sociais para uma visão de direitos individuais foi chamada de "pós feminismo", uma concepção que deriva de uma despolitização de uma série de objetivos centrais do feminismo de segunda onda, em nome da noção de livre arbítrio derivada do protestantismo.

Uma das consequências deste período, no plano ideológico, foi a de que uma série de trabalhadoras que acreditavam no direito à igualdade no trabalho estavam prontas a rejeitar a caracterização enquanto "feministas". Há análises de que esta recusa contraditória (afinal, a igualdade no trabalho é evidentemente compatível com o feminismo) teria se dado por conta de orientações prescritivas que passaram a fazer parte do feminismo nos anos 1980, no sentido do que "não fazer" comportamental, que teriam inclinado

${ }^{25}$ As referências a esta autora no texto têm tradução livre nossa. 
as mulheres à força de sedução do laissez-faire da direita (SKEGGS, 2015, p. 179).

Skeggs (2015, p. 281) pontua que é neste período que ocorre, no contexto da Grã-Bretanha, uma dissociação entre um feminismo da cultura popular e um feminismo do mundo do trabalho - o foco do feminismo, neste contexto, de deslocou de uma luta política coletiva a um feminismo de sucesso midiático ${ }^{26}$. Aspectos individualistas do feminismo, tais como poder sexual, autonomia, respeito, auto estima, foram explorados comercialmente e conseguiram atrair seletivamente com a intenção de superar divisões de classe e de raça em nome do desejo de ser autônoma, poderosa, confiante, glamorosa etc. Fazendo isso, este feminismo de desvincula da dimensão social e sistêmica e se reduz ao indivíduo solitário, tornando invisíveis os sentidos de responsabilidade coletiva e os vinculos entre as mulheres, para além de suas distinções ${ }^{27}$ (SKEGGS, 2015, p 282).

Fraser $(2009,2013)$ acredita que a inflexão de sentido do feminismo acompanha a transformação na natureza do capitalismo: de administrado pelo Estado no contexto pós-guerra, passa à forma do de um capitalismo "desorganizado", globalizado, neoliberal.

A autora aponta, então, que ao menos três críticas feministas cujo sentido original era emancipatório foram cooptadas em favor deste sentido neoliberal:

(i) a crítica ao salário familiar pago ao homem é utilizada para legitimar o "capitalismo flexível" que depende do trabalho assalariado feminino, sobretudo nas manufaturas e nos serviços, com baixa remuneração. A norma moderna em substituição ao salário familiar é o da família de dois assalariados (pouco importando o nível rebaixado de direitos, proteções sociais, jornada estendida, aumento da pobreza em lares chefiados por mulheres). O ideal de emancipação das mulheres passa a se enquadrar na narrativa de empoderamento feminino, "ser assalariada como o homem" se torna um horizonte, ao invés de não ser explorada pelo capitalismo.

\footnotetext{
${ }^{26}$ Quando surgem como referências "pop proto-feministas" artistas como Madonna, Cindy Lauper e Aretha Franklin (SKEGGS, 2015, p. 281)

${ }^{27}$ Grifo nosso.
} 
(ii) a crítica feminista ao não reconhecimento das ditas "injustiças não econômicas" (violência às mulheres, opressão reprodutiva) que configurava a crítica ao economicismo, trazia em seu bojo uma intenção de alargamento da agenda política. Mas ao invés de expandir a luta pela justiça de modo a que englobasse tanto a dimensão da cultura como a da economia, a primeira passou a ser absolutizada em detrimento da segunda, justamente em tempos de um neoliberalismo ascendente ao qual é conveniente o ocultamento de toda a memória de desigualdade social.

(iii) a crítica a um Estado paternalista estaria convergindo com o combate neoliberal ao Estado "provedor", sendo um dos exemplos os programas de microcréditos às mulheres no sul global. Estes são considerados uma alternativa "empoderadora" por vir "de baixo" e transpor burocracias do Estado, e são vistos por certos setores do feminismo como antídoto para a pobreza e sujeição das mulheres. Contudo, não pode ser esquecida a coincidência de que a aparição das políticas de microcrédito se deu justamente quando os Estados abandonaram seus esforços macro para o combate à pobreza. Uma ideia feminista voltada originalmente para democratizar o poder do Estado é incorporada e cooptada pelo neoliberalismo para legitimar a mercantilização e amputação do Estado.

Isso leva a refletir sobre um desafio nos tempos atuais: o de que embora haja sob o neoliberalismo fortes tendências de uma considerável piora nas condições de trabalho e de vida do conjunto dos trabalhadores, sobretudo das mulheres, o capitalismo "flexível" teria elaborado, analisa Fraser, (2009, p. 25), uma nova narrativa de avanço feminino centrada no "reconhecimento" mas apartada da economia política. Nos dois extremos do grupo social mulheres trabalhadoras - as profissionais de classe média lutando contra o teto de vidro e as trabalhadoras "precárias" - o sonho de emancipação das mulheres estaria subordinado à máquina de acúmulo capitalista.

Neste contexto de reorganização neoliberal do trabalho, há atividades confiadas maciçamente às mulheres racializadas e empobrecidas com base não em uma "natureza", mas em um conjunto de leis e instituições que as impele e orienta para os trabalhos onde são necessárias. Mulheres são 
convocadas para estas relações de apropriação e exploração, mas há para elas “a apaziguante impressão de escolher” (FALQUET, 2013, p. 23). Tal "impressão de escolher" que se depura da construção de relações individualistas pode ser uma tática neoliberal para cooptar lutas feministas por autonomia e fazer mulheres acreditarem serem expressão da sua liberdade as atividades que consistem em sua exploração e/ou apropriação.

Diante deste cenário, Fraser (2002) propõe, como forma de se evitar que as feministas involuntariamente "conspirarem" com o neoliberalismo, que revisitem o conceito de gênero, acomodando nele tanto a problemática do trabalho como a da cultura. Deste modo, para reativar a promessa emancipatória para as mulheres, Fraser (2009, p. 28) aponta como saída uma análise tridimensional da injustiça (política, econômica e cultural) que deve "reconectar a crítica feminista à crítica do capitalismo" e assim reposicionar o feminismo na esquerda. Esta batalha pela recuperação do sentido das pautas feministas cooptadas pelo neoliberalismo engloba como bandeiras, para a autora, a luta pela valorização do trabalho assalariado e das atividades não salariais das mulheres, a luta por justiça econômica combinada com o combate à cultura machista e a luta por democracia e fortalecimento dos poderes públicos.

\section{CONSIDERAÇÕES FINAIS}

O debate sobre globalização e divisão sexual do trabalho tende a se renovar em um contexto de realinhamento neoliberal em países como o Brasil e demais da América Latina, após vivenciarem curto período de implantação de políticas socioeconômicas por governos progressistas que minoraram os impactos de uma neoliberalização "tout court" que vinha se desenvolvendo desde os anos 1990.

Considero possível afirmar que alguns dos avanços no trabalho conquistados pelas mulheres estão em xeque em tempos de neoliberais de capitalismo "flexível". Ampliam-se as tendências de as mulheres serem reconvocadas a trabalhos precários dos quais uma parcela havia conseguido sair (por exemplo, no Brasil, o trabalho doméstico assalariado ou trabalhos instáveis nas áreas do comércio e serviços), assim como cresce o desemprego. 
Contudo, existe a tendência, como sinalizam Hirata e Kergoat, de se aprofundar a bipolaridade do trabalho feminino e a se acirrarem conflitos de classes entre mulheres, uma vez que existe um pequeno grupo destas que vem ascendendo à posição de detentoras ou gestoras do capital.

Estas mulheres tendem a ser as protagonistas das narrativas sobre "avanço feminino" que vêm se difundindo recentemente, em uma versão palatável de feminismo que se dissocia de debates da economia política e se sustenta na valorização das conquistas individuais de "self made women", empreendedoras. Trata-se da reprodução do discurso neoliberal da integração e sucesso no capitalismo pelo mérito, tratando sucessos ou fracassos como processos que só dependem da vontade individual, naturalizando-se o concorrencialismo e minando-se a solidariedade, só que no feminino.

O atual debate "triunfalista" da ascensão feminina, que diga-se de passagem, também existiu nos anos 1990 (Skeggs, 2015), é incompatível com a compreensão das desigualdades como estruturais; não cabe nele o questionamento do modelo socioeconômico capitalista ou da reprodução das relações patriarcais como causas de desigualdades: pelo contrário, ele justamente retoma, com porta-vozes femininas, o debate sobre integração das mulheres e de construção de igualdade no capitalismo.

Enquanto isso, há o outro lado da moeda: a busca de vantagens competitivas nos processos de internacionalização da produção e do comércio se conforma como um processo sexuado, o qual permite colocar em evidência o uso da força de trabalho feminino nas pontas de cadeias globais como uma conduta marcante em setores de utilização de mão de obra intensiva e produção eminentemente manual. Este é um elemento que precisa ser considerado na análise econômica: as mulheres são centrais nas cadeias globais de valor e seu trabalho tem sido fator chave nos processos de "taylorização primitiva" que recuperam os mecanismos originários da acumulação capitalista. Este lado oculto da divisão sexual e internacional do trabalho coloca em xeque a visão triunfalista de avanço feminino das mulheres no "capitalismo flexível". Não há discurso de empoderamento que encubra relações de exploração, assédios, sobrecargas laborais, trabalho 
insalubre e inseguro ou mesmo mortes de trabalhadoras que estão em um dos pilares da produção de mais valia global: as indústrias de manufatura.

A análise que leva em conta a divisão sexual do trabalho permite reconhecer que existe um uso estratégico de força de trabalho feminina em manufaturas de eletroeletrônicos, algo que a literatura já reconhece sobre as cadeias de confecções. A divisão sexual do trabalho observada em âmbito internacional e também no interior de empresas mostra que a problemática da busca global de força de trabalho de baixo custo não é indiferente aos sexos, mas que privilegia-se o uso da força de trabalho feminina por conta da sua qualificação informal em trabalhos que exigem motricidade fina (não oficialmente reconhecida), por ser vista como mão de obra mais facilmente controlável (herança das relações de subjugação patriarcais) e por ser um contingente da classe trabalhadora que ocupa as bases da pirâmide do mercado de trabalho (segregadas em trabalhos mais precários com pior remuneração, sobretudo as negras), o que as faz ver nos trabalhos em manufaturas, por vezes, uma condição de "ascensão" em relação a trabalhos precedentes (serviços, trabalho doméstico, trabalho no campo).

Vale salientar sob o capitalismo neoliberal desenvolvem-se que não somente renovadas formas de exploração, mas também de apropriação, a exemplo das políticas de austeridade que cortam o orçamento público ou das políticas de isenção tributária a empresas que desfinanciam o Estado, resultando em uma redução das políticas que significavam, ainda que parcialmente, socialização do trabalho reprodutivo com o Estado (creches, escolas, serviços de saúde públicos) - um processo que (re)coloca estas funções a cargo das mulheres, a serem realizadas gratuitamente. O capital expande, assim, seus meios de acumulação explorando e espoliando os corpos e o trabalho das mulheres.

É possível afirmar que no atual contexto existe uma manutenção dos princípios básicos de separação e hierarquização do trabalho entre os homens e as mulheres nos trabalhos reprodutivo e assalariado, embora as condições de subordinação tenham ganhado contornos distintos sob o capitalismo flexível, além de haver adicionalmente o componente ideológico de cooptação neoliberal individualista das lutas por emancipação feminina, que afeta a compreensão das trabalhadoras 
sobre a própria condição de subordinação. Portanto, a luta contra esta divisão sexual pode ser efetiva se operada em conjunto contra a superação das relações sociais de classe e de raça, se for compreendida a co-produção entre trabalho assalariado e reprodutivo e se forem levadas em conta as dimensões materiais e subjetivas de avanço neoliberal.

Há de se considerar, neste sentido, as contribuições de organizações feministas a exemplo da Marcha Mundial de Mulheres, que tem desde sua origem um posicionamento político antiglobalização neoliberal, além de ter sido uma importante difusora e também adepta das elaborações de economistas feministas:

Hoje tem sido frequente nos debates feministas a reflexão em termos de interseccionalidade, consubstancialidade ou imbricação das relações sociais de classe, raça e sexo. Desde a nossa perspectiva, olhar para o conjunto do trabalho necessário para a sustentabilidade da vida nos permite compreender melhor as imbricações dessas relações sociais. Isso porque amplia o debate para além das representações, e permite questionar o conjunto das dinâmicas geradoras das desigualdades. Quando o feminismo não é constitutivamente antipatriarcal, antirracista e anticapitalista, suas reivindicações não apenas invisibilizam a maioria das mulheres, mas também são incorporadas as custas dessa maioria, ampliando a exploração sobre elas (MARCHA Mundial de Mulheres, 2018, p. 8).

Resta reafirmar e fortalecer um sentido de feminismo (nos sindicatos, nos movimentos feministas e demais movimentos sociais, na sociedade como um todo) que combata a exploração e apropriação do trabalho pelo capitalismo neoliberal, assim como produzir resistências à dimensão ideológica-individualista, buscando recuperar relações de solidariedade tão bem sintetizadas na insígnia "permanecer em luta até que todas sejam livres". Perder de vista a lógica do capital mundializado pode levar a saídas insuficientes para superar a subjugação das mulheres. É preciso, pois, mudar o mundo neoliberal e a vida das mulheres como parte de um mesmo processo.

Temáticas, Campinas, 26, (52): 247-284, ago./dez. 2018 


\section{REFERÊNCIAS BIBLIOGRÁFICAS}

ABRAMO, Laís W. "Cadeias produtivas, segmentação de gênero e novas formas de regulação: notas metodológicas a partir de uma experiência de pesquisa" in Gitahy, 1. Y Leite, M. (org) Novas tramas produtivas: Uma discussão teórico-metodológica. São Paulo, Ed. SENAC, 2005.

BELluZZO, Luiz Gonzaga; GALÍPOLO, Gabriel. Manda quem pode, obedece quem tem prejuíro. Edição Kobo (e-book). São Paulo: Editora Contracorrente, 2017.

CAMPOS, André; GOMES, Marcel; SCHIPPER, Irene. Labour conditions at foreign electronics manufacturing companies in Brazil. Case studies of Samsung, LGE and Foxconn. São Paulo/Amsterdam: Repórter Brasil, SOMO, Good Eletronics, 2017.

CARRASCO, Cristina. Para uma Economia Feminista - Introdução. (Trad: Sempreviva Organização Feminista). In: Mujeres y economia. Nuevas perspectivas para viejos e nuevos problemas. (ed.) Cristina Carrasco. Icaria. Barcelona. 1999.

CHESNAIS, François. "A Globalização e o curso do capitalismo de fimde-século". In: Economia e sociedade, Campinas, n.5, dez. 1995, p.1-30. - A mundialização do capital. São Paulo: Xamã, 1996.

DIEESE/Subseção CNM-CUT - FEM-CUT/SP. A inserção das mulheres no ramo metalúrgico. Uma década de avanços, desafios e lutas. São Bernardo do Campo, 2017.

DUNAWAY, Wilma A. Bringing Commodity Chain Analysis Back to its World-Systems Roots: Rediscovering Women's Work and Households. American Sociological Association, V. 20, N.1, p. 64-81, 2014.

DUARTE, Christian; SALAS, Carlos. As novas e velhas máscaras da terceirização no capitalismo contemporâneo. Campinas: CESIT, 2017 Disponível em: $\quad<$ http://www.cesit.net.br/as-novas-e-velhas-mascaras-daterceirizacao-no-capitalismo-contemporaneo $>$. Acesso em 5 jul. 2017. 
ELSON, Diane. PEARSON, Ruth. Nimble fingers make cheap workers: an analysis of woman employment in third world manufacturing. Feminist Review. Paris, n. 7, p. 87-107, 1981.

ELSON, Diane. "Commerce interntional, égalité des sexes et avantage compétitif”. In: FALQUET, Jules; HIRATA, Helena; KERGOAT; Danièle et. Al (orgs). Le sexe de la mondialisation. Genre, classe, race et nouvelle division du travail. Paris, Presses de Sciences Po, 2010.

FALQUET, Jules. O capitalismo financeiro não liberta as mulheres: análises feministas materialistas e imbricacionistas. Critica Marxista. n 36, Campinas, 2013. p. 9-25

. "Transformações neoliberais do trabalho das mulheres: liberação ou novas formas de apropriação?" In: ABREU, Alice R. P. A; HIRATA, Helena; LOMBARDI, Maria R. Gênero e trabalho no Brasil e na França: perspectivas interseccionais. São Paulo: Boitempo, 2016.

; HIRATA, Helena; KERGOAT; Danièle et. A (orgs). Le sexe de la mondialisation. Genre, classe, race et nouvelle division du travail. Paris, Presses de Sciences Po, 2010.

; HIRATA, Helena; LAUTIER, Bruno. Les nouveaux paradoxes de la mondialisation (Introduction). In: FALQUET, Jules; HIRATA, Helena; LAUTIER, Bruno (coords). Cahiers du Genre. Travail et mondialisation. Confrontations Nord Sud.v.1. n.40. Paris: L'Harmattan, 2006.

FARINACCIO, Rafael. "Uma visita na "fábrica de suicídios" da Apple na China. Techmundo. 20 jun 2017. Disponível em: <https://www. tecmundo.com.br/apple/118036-visita-fabrica-suicidios-apple-nachina.htm> Acesso em 01 set. 2018.

FRASER, Nancy. Políticas feministas na era do reconhecimento: uma abordagem bidimensional da justiça de gênero. Gênero, democracia e sociedade brasileira. São Paulo: Editora 34, 2002. 
. O feminismo, o capitalismo e a astúcia da história. Dossiê: Contribuições do pensamento feminista para as Ciências Sociais. Mediações: Revista de Ciências Sociais. Londrina, v. 14, n. 2, jul./dez. 2009.

- How feminism became capitalism's handmaiden and how to reclaim it. 14 out. 2013, The Guardian. Disponível em: <https://www.theguardian.com/commentisfree/2013/oct/14/ feminism-capitalist-handmaiden-neoliberal $>$. Acesso em: 05 mar. 2018.

FEDERICI, Silvia. O calibã e a bruxa. Mulheres, corpo e acumulação primitiva. São Paulo, Editora Elefante, 2017.

GUILLAUMIN, Colette. Pratique du pouvoir et idée de nature. In . Sexe, Race et pratique du pouvoir. L'idée de nature. 1 ed. 1978. Paris, Côté-femmes, 1992.

HARVEY, David. Novo imperialismo. São Paulo: Edições Loyola, 2004.

Loyola, 2008. O neoliberalismo: história e implicacõoes. São Paulo, Edições

HIRATA, Helena. Da polarização das qualificações ao modelo de competência". In: FERRETTI, C. et. al. (orgs.). Novas Tecnologias, trabalho e educação: um debate multidisciplinar. Petrópolis: Vozes, 1994. p. $128-137$.

. Globalização e divisão sexual do trabalho. Cadernos Pagu, n.17/18 (02). Campinas: 2001, pp. 139-156.

. Mudanças e permanências nas desigualdades de gênero: divisão sexual do trabalho numa perspectiva comparativa. Análise $\mathrm{n}$. 7, Friedrich-Ebert-Stiftung (FES) Brasil, out. 2015

HIRATA, Helena; KERGOAT, Danièle. Divisão sexual do trabalho profissional e doméstico: Brasil, França, Japão. In: COSTA, Albertina O. et.al (orgs). Mercado de Trabalho e Gênero: Comparações Internacionais. Rio de Janeiro: Editora FGV, 2008. 
JENSON, Jane. The talents of women, the skills of men: flexible specialization and women. In: WOOD, S. (ed.). The Transformation of work? Skill, flexibility and labour process. London: Unwin Hyman, 1989.

KERGOAT, Danièle. Pladoyer pour une sociologie des rapports sociaux. De l'analyse critique des catégories dominantes à la mise em place d'une nouvelle conceptualisation. In: ARTCHEVSKY-BULPORT, A. et al. Le sexe $d u$ travail. Structures familiales et système productif. Presses universitaires de Grenoble, 1984.

. Dinâmica e consubstancialidade das relações sociais. Revista Novos Estudos, n. 86, p. 93-103, mar. 2010.

. Compreender as lutas das mulheres por sua emancipação pessoal e coletiva. In: Feminismo, economia e política. Debates para a construção da igualdade e autonomia das mulheres. São Paulo: SOF, 2014.

KLAGSBRUNN, Victor Hugo. Uma leitura crítica dos conceitos de mundialização do capital e de regime de acumulação com predominância financeira. Crítica Marxista, n.27, p.27-46, 2008.

LAPA, Thaís S. Processo de trabalho, divisão sexual do trabalho e práticas sociais das operárias na indústria eletroeletrônica no contexto da flexibilidade produtiva. Dissertação de Mestrado. Faculdade de Filosofia, Letras e Ciências Humanas, Universidade de São Paulo, São Paulo, 2014.

- Trabalho (Des)qualificado e controle gerencial no setor eletroeletrônico no Brasil: Problematizações a partir da perspectiva de gênero. In SILVA, Leonardo Mello E (org). Exercícios de Sociologia do Trabalho. Belo Horizonte, Fino Traço, 2016a. pp. 127-156.

Desigualdade salarial por sexo: persistências, transformações e desafios. Dossiê: Relações de Gênero, Raça e Etnia no Mercado de Trabalho Brasileiro no Século XXI. Revista da ABET, v. 15, n. 1, Janeiro a Junho de 2016b. pp. 127-137. Disponível em: < http://periodicos.ufpb.br/index.php/abet/article/ view/31264/16341> Acesso em 6 Dez. 2018. 
.; LEITE, Marcia P. “O trabalho no setor eletroeletrônico: O Brasil na cadeia global”. In: SALAS, Carlos;KREIN, José Dari; BIAVASCHI, Magda Barros; LEITE, Marcia de Paula (Orgs). Trabalho e regulação em perspectiva comparada. São Carlos, Editora da UFSCar, 2017, pp. 311-330.

LEITE, Marcia. Trabalho e sociedade em transformação. Mudanças produtivas e atores sociais. São Paulo: Editora Fundação Perseu Abramo, 2003.

. O trabalho (re)visitado: Uma discussão metodológica. In GITAHY, Leda; LEITE, Marcia P. (orgs). Novas tramas produtivas. Uma discussão teórico-metodológica. São Paulo, Editora Senac, 2005, pp. 201-232.

; SILVA, Sandra R.A.; GUIMARÃES, Pilar Carvalho. O trabalho na confecção em São Paulo: as novas formas de precariedade. Cad. CRH, Salvador, v. 30, n. 79, p. 51-67, Abr. 2017. Disponível em: $<$ http:/ /www.scielo.br/scielo.php?script=sci_arttext\&pid=S010349792017000100051\&lng=en\&nrm=iso> Acesso em 01 Set. 2018.

LIMA, Mariana. Brasiljá tem mais de um smartphone ativo por habitante, diz estudo da FGV.19 abr. 2018. Estadão. Disponível em: < https://link.estadao. com.br/noticias/geral,brasil-ja-tem-mais-de-um-smartphone-ativopor-habitante-diz-estudo-da-fgv,70002275238>. Acesso em 02 set. 2018.

LIPIETZ, Alain. Fordismo, fordismo periférico e metropolização. Porto Alegre: Ensaios FEE, 10(2): pp 303-335, 1989.

MARCHA Mundial de Mulheres. Desafios feministas para enfrentar o conflito do capital contra a vida -nós mulheres seguimos em luta! São Paulo: SOF Sempreviva Organização Feminista e Marcha Mundial das Mulheres, 2018.

PUN, Ngai. Made in China. Women Factory Workers in a Global Workplace. Durhan e Londres: Duke University Press / Hong Kong: Hong Kong University Press, 2006. 
SARTI, Fernando; HIRATUKA, Celio. Desempenho recente da indústria brasileira no contexto de mudanças estruturais domésticas e globais. In: CARNEIRO, Ricardo; BALTAR, Paulo; SARTI, Fernando (orgs). Para Além da Política Econômica. São Paulo: Editora Unesp Digital, 2018.

SASSEN, Saskia. The Global City. New York, London, Tokyo. Saskia Sassen, Princeton-New Jersey: Princeton University Press, 1991.

SKEGGS, Berveley. Des Femmes Respectables. Classe et genre em milieu populaire. Agone, Marseille, 2015.

TEITEBAUM, Alejandro. A catástrofe do Bangladesh: uma amostra grátis do capitalismo mundializado. (Trad. Bruno Góis). Diário da Liberdade. 11 ago 2013. Disponível em: <https://www.diarioliberdade.org/ mundo/reportagens / 40844-a-cat $\%$ C3\%A1 strofe-do-bangladeshuma-amostra-gr $\% \mathrm{C} 3 \% \mathrm{~A} 1$ tis-do-capitalismo-mundializado.html> . Acesso em: 01 set 2018.

Submetido em 26/05/2018.

Revisado em 10/09/2018.

Aceito em 11/09/2018. 